\title{
Gene Expression in Antifungal Resistant and Susceptible Isolates of Candida albicans
}

\author{
M. A. Sayed ${ }^{1}$, T. M. A. Abdel-Rahman'; H.M. Hassaneen'; \\ A. A. El Kholy ${ }^{3}$ and R. M. Naguib ${ }^{4}$ \\ ${ }^{1}$ Botany Department, ${ }^{2}$ Chemistry Department, Faculty of Science, \\ ${ }^{3}$ Clinical Pathology, Faculty of Medicine, and ${ }^{4}$ Microanalytical \\ Center, Faculty of Science, Cairo University, Giza, Egypt.
}

\begin{abstract}
GUSCEPTIBILITY assays using white and opaque Candida Salbicans were performed against two antifungals: fluconazole (FLU) and terbinafine (TRB). The microdilution method (NCCLS $\mathrm{M} 27-\mathrm{A} 2$ ) was used for determination of the $\mathrm{MIC}_{90}$. It was found that FLU and TRB were active antifungal drugs against $C$. albicans either in white or opaque forms but FLU more efficient than TRB.

The expression of five resistance genes was measured by RT-PCR after treatment of $C$. albicans with both FLU and TRB. The results indicated that Candida drug resistant gene CDRI was expressed in susceptible and resistant isolates. However, Candida drug resistant gene $C D R 2$, Candida multidrug resistant gene CaMDR1 and ergosterol resistant gene ERG11 were up regulated in only resistant $C$. albicans against FLU and TRB. Fluconazole resistant gene FLU1 in C. albicans not expressed at all antifungal treatments.
\end{abstract}

Keywords: Candida albicans, Antifungal drugs, Resistance genes.

Fluconazole is water-soluble and highly bio-available, permitting both intravenous and oral formulations. It has low binding to plasma proteins and a long plasma half-life ( $31 \mathrm{hr}$ in adults). Penetration of FLU into the Cerebrospinal fluid (CSF), brain, liver, spleen, and kidneys is excellent. It is excreted unchanged in the urine, making it an excellent agent for the treatment of Candida urinary tract infections (Kucers et al., 1997). As with all azoles, FLU is fungistatic. It is usually active against Candida albicans, C. parapsilosis, C. tropicalis, and C. lusitaniae. Intrinsic resistance to FLU has been observed in C. krusei and C. glabrata (Casalinuovo et al., 2004). FLU is the only azole with significant data on use in neonatal populations. The initial neonatal dosing information was developed in a study using FLU as prophylaxis during a $C$. parapsilosis outbreak (Saxen et al., 1993).

Recently, fluconazole-resistant $C$. albicans strains and intrinsically resistant Candida species such as $C$. glabrata and $C$. krusei are emerging in immunocompromised patients treated for therapy or prophylaxis (Case et al., 1991; Krcmery and Barnes, 2002). 
Terbinafine hydrochloride is a synthetic allylamine antifungal has been developed as a new class of ergosterol biosynthetic inhibitors that are functionally as well as chemically distinct from the other major classes of ergosterol-inhibiting antifungal agents (Ryder et al., 1984; Ryder and Favre, 1997). The mechanism of action of terbinafine involves the specific inhibition of fungal squalene epoxidase, resulting in ergosterol deficiency and accumulation of intracellular squalene, which appears to be identical in dermatophytes, molds, and yeasts (Ryder, 1992; Graminha et al., 2004).

C. albicans resistance to antifungal agent is due to expression of resistance gene(s) associated with antifungal treatment. These genes include Candida drug resistance genes (CDR1 and $C D R 2)$ they encoding transporters of ATP-binding cassette $(\mathrm{ABC})$ family; multi-drug resistance gene (CaMDR1) which coding a major facilitator transporters (MFT) family; fluconazole-resistance genes; (FLU1) and (ERG11) encoding lanosterol 14- $\alpha$ demethylase (Chen et al., 2010).

The objective of the present study was to assay the susceptibility of $C$. albicans isolates to some antifungals. The upregulation of some resistance genes in C. albicans in response to antifungal treatments were also studied.

\section{Material and Methods}

Antifungal assay by disk-diffusion susceptibility method

The primary screening of $C$. albicans isolates was carried out by the diskdiffusion method using agar medium (CLSI M44-A), according to the Clinical and Laboratory Standards Institute guidelines (CLSI, 2009). The antifungal drugs showing an inhibitory effect on the growth of the tested Candida isolates was monitored as an appearance of growth inhibition zone (GIZ).

Estimation of minimum inhibitory concentration $\left(M^{2} C_{90}\right)$ using broth microdilution technique (M27-A2)

Liquid RPMI 1640 medium with L-glutamine and 2\% glucose but without bicarbonate (Rodriguez-Tudela et al., 1996) was buffered with morpholinepropanesulfonic acid (MOPS) to $\mathrm{pH} 7$ at $25^{\circ} \mathrm{C}$, and applied in sterile 96 round-bottom wells microtiter plate made of polypropylene (Nunc ${ }^{\circledR}$, Roskilde, Denmark) containing different dilutions of antifungal. Thawing was accomplished by setting the inoculated plates in the $4^{\circ} \mathrm{C}$ refrigerator for $1 \mathrm{hr}$ leaving them at room temperature for another $1 \mathrm{hr}$, and finally placing them in the $35^{\circ} \mathrm{C}$ incubator for 15 to $30 \mathrm{~min}$ to minimize condensation formation on the plate lids. The plate lids also were propped up slightly to allow evaporation of condensate during all three stages of the thawing procedure. $\mathrm{MIC}_{90}$ was defined as the concentration of the antifungal that inhibit $90 \%$ of the $C$. albicans growth. 
Resistance gene expressions in C. albicans isolates Total RNA isolation

For each isolate, an overnight culture was propagated in fresh yeast extract peptone dextrose broth with constant shaking at $30^{\circ} \mathrm{C}$ until the mid-logarithmic phase was reached. Total cellular RNA was extracted with the TRIzol reagent (Invitrogen, Carlsbad, CA, USA) according to the supplier's instruction. Possible genomic DNA contamination was removed by RNase-free DNase I (Fermentas Life Sciences, Burlington, ON, Canada) treatment. Total RNA concentrations were determined spectrophotometrically at $260 \mathrm{~nm}$ using a spectrophotometer (SHIMADZU UV-1650PC, Japan): a ratio of $\mathrm{A}_{260} \mathrm{~nm}$ : $\mathrm{A}_{280} \mathrm{~nm}$ of 1.8- 2.0 corresponded to $90-100 \%$ pure nucleic acid. Analytical denaturing RNA electrophoresis in TAE agarose gels was carried out based on the method of Masek et al. (2005) employing the Tris-acetate-EDTA buffer (TAE) with denaturation of the sample in $50 \%$ formamide prior to electrophoresis.

Reverse transcription polymerase chain reaction (RT-PCR) analysis

In order to determine expression genes patterns of $C$. albicans $C D R 1, C D R 2$, ERG11, FLU1 and CaMDR1 semi-quantitatively, RT-PCR was conducted on total RNA extracted from the most susceptible- and most resistant isolates to fluconazole and terbinafine either white or opaque isolates (Table 1).

TABLE 1. C. albicans isolates used for resistance genes expression .

\begin{tabular}{|c|c|c|c|c|c|c|c|}
\hline \multicolumn{4}{|c|}{ Fluconazole group } & \multicolumn{4}{|c|}{ Terbinafine group } \\
\hline \multicolumn{2}{|c|}{ Susceptible } & \multicolumn{2}{|c|}{ Resistant } & \multicolumn{2}{|c|}{ Susceptible } & \multicolumn{2}{|c|}{ Resistant } \\
\hline $\begin{array}{c}\text { Opaque } \\
\mathrm{C} 1\end{array}$ & $\begin{array}{c}\text { White } \\
\text { C2 }\end{array}$ & $\begin{array}{c}\text { Opaque } \\
\text { C3 }\end{array}$ & $\begin{array}{l}\text { White } \\
\text { C4 }\end{array}$ & $\begin{array}{l}\text { Opaque } \\
\text { C5 }\end{array}$ & $\begin{array}{l}\text { White } \\
\text { C6 }\end{array}$ & $\begin{array}{c}\text { Opaque } \\
\text { C7 }\end{array}$ & $\begin{array}{c}\text { White } \\
\text { C8 }\end{array}$ \\
\hline
\end{tabular}

The cDNA for each strain was synthesized using the extracted total RNA with 200 units of RevertAid ${ }^{\mathrm{TM}}$ M-MuLV Reverse Transcriptase from the RevertAid ${ }^{\mathrm{TM}}$ First Strand cDNA Synthesis Kit (Fermentas Life Sciences) and an oligo (dT) primer [a cDNA synthesis primer $(10 \mu \mathrm{M})]$ with the dNTP mixture $(10 \mathrm{mM})$. The generated cDNA was then used as a template in PCR reactions. The PCR primers used to amplify and identify the C. albicans CDR1, CDR2, ERG11, FLU1 and $C a M D R 1$ genes were designed with Primer Premier 5.0 design software (Premier Biosoft International, Palo Alto, CA, USA) and synthesized by BIONEER Inc. (Dalian, Korea). The housekeeping gene $18 S r R N A$ was used as a control. The nucleotide sequences of the primers are given (Table 2). 
TABLE 2. Nucleotide sequences of primers used to amplify the study of resistance genes in 8 C. albicans isolates using a semi-quantitative RT-PCR (Semi Q RT-PCR) approach .

\begin{tabular}{|c|c|c|c|}
\hline Gene & $\begin{array}{l}\text { Product } \\
\text { length } \\
\text { (base } \\
\text { pairs) }\end{array}$ & $\begin{array}{c}\text { Directio } \\
\mathbf{n}\end{array}$ & Primer sequences \\
\hline \multirow{2}{*}{$C D R 1$} & \multirow{2}{*}{93} & $\mathrm{~F}$ & 5'-TGTGTACTATCCATCAACCATCAGC-3' \\
\hline & & $\mathrm{R}$ & 5'-CACCAAAATAAGCCGTTCTACCA-3' \\
\hline \multirow{2}{*}{$C D R 2$} & \multirow{2}{*}{125} & $\mathrm{~F}$ & 5'-TGGCAAACAATCCAACAATACA-3' \\
\hline & & $\mathrm{R}$ & 5'-AATCAAGGGAATAGATGGGTCA-3' \\
\hline \multirow{2}{*}{ CaMDRl } & \multirow{2}{*}{148} & $\mathrm{~F}$ & 5'-TCAGCGGGTTCTTTGTTGTATG-3' \\
\hline & & $\mathrm{R}$ & 5'-GATAATGTTTAGCAAGCCGAGGA-3' \\
\hline \multirow{2}{*}{ ERG11 } & \multirow{2}{*}{134} & $\mathrm{~F}$ & 5'-TTTGGTGGTGGTAGACATA-3' \\
\hline & & $\mathrm{R}$ & 5'-GAACTATAATCAGGGTCAGG-3' \\
\hline \multirow{2}{*}{ FLU1 } & \multirow{2}{*}{92} & $\mathrm{~F}$ & 5'-GTGGTAAAATCATCCCCGAAAA-3' \\
\hline & & $\mathrm{R}$ & 5'-CCAGTCCAACCAAGCCAGA-3' \\
\hline \multirow{2}{*}{ 18SrRNA } & \multirow{2}{*}{150} & $\mathrm{~F}$ & 5'-TCTTTCTTGATTTTGTGGGTGG-3' \\
\hline & & $\mathrm{R}$ & 5'-TCGATAGTCCCTCTAAGAAGTG-3' \\
\hline
\end{tabular}

ERG11, lanosterol 14 $\alpha$-demethylase gene; CDR1, Candida drug resistance 1 gene; CDR2, Candida drug resistance 2 gene; CaMDR1, Candida multidrug resistance 1 gene; FLU1, fluconazole resistance 1 gene. F, Forward; R: reverse.

In this study different PCR assays were performed in $25 \mu \mathrm{L}$ PCR reaction volume. The amplification was performed in a programmable heating block (Primus Thermal Cycler, MWG Biotech, Germany). The PCR conditions for all the genes except ERG11 was: Initial denaturation of $95^{\circ} \mathrm{C}$ for $3 \mathrm{~min}$ followed by 40 cycles of denaturation at $95^{\circ} \mathrm{C}$ for 45 seconds, annealing at $50^{\circ} \mathrm{C}$ for 45 seconds, and extension at $72^{\circ} \mathrm{C}$ for $1 \mathrm{~min}$. While, the PCR conditions for ERG11 was: Initial denaturation of $95^{\circ} \mathrm{C}$ for $3 \mathrm{~min}$, followed by 40 cycles of denaturation at $95^{\circ} \mathrm{C}$ for 45 seconds, annealing at $42^{\circ} \mathrm{C}$ for 45 seconds, and extension at $72^{\circ} \mathrm{C}$ for $1 \mathrm{~min}$, followed by final extension at $72^{\circ} \mathrm{C}$ for $10 \mathrm{~min}$.

Visualization and quantitation of PCR products

After amplification, $10 \mu 1$ of each PCR product was mixed with $2 \mu 1$ of the orange/Blue 6X loading dye (Promega). Samples were electrophoresed on $1.5 \%$ agarose gel in $0.5 \times \mathrm{TBE}$ buffer containing $0.5 \mu \mathrm{g} / \mathrm{ml}$ ethidium bromides for $50-60$ minutes at 70 volts in a minigel electrophoresis unit using $0.5 \times \mathrm{TBE}$ as electrophoresis buffer. Amplification products were visualized and photographed using ultraviolet transilluminator. The sizes of the amplification products were compared with either the $100 \mathrm{bp}$ ladder DNA marker that was loaded with the samples simultaneously. Quantitation of RT-PCR produced band intensity, strength, was carried out in Image $\mathbf{J}$ software.

\section{Statistical analyses}

Duncan test was executed to show homogeneity among the means at $(P<0.05)$. Statistical analyses were performed using SPSS software (version 15; SPSS, Chicago, IL).

Egypt. J. Bot., 54, No. 1 (2014) 


\section{Results}

\section{1- Antifungal susceptibility assay}

Table 3 reveal that the opaque isolates $\mathrm{C} 1$ and $\mathrm{C} 3$ were more susceptible to FLU than the white ones, $\mathrm{C} 2$ and $\mathrm{C} 4$. The highly resistant isolate $\mathrm{C} 4$ was collected from blood of a male of 2 months age, suffering from immunodeficiency and treated with three types of antibiotics. On the other hand, the highly susceptible isolate $\mathrm{C} 1$ was collected from the urine of a male of 2 months age suffering from pynophrosis and treated with two types of antibiotics.

TABLE 3. $\mathrm{MIC}_{90}$ values for $\mathrm{FLU}$ against $C$. albicans isolates .

\begin{tabular}{|c|c|c|c|c|}
\hline \multirow{2}{*}{ Treatment } & \multicolumn{4}{|c|}{ MIC $_{\mathbf{9 0}}(\mu \mathrm{g} / \mathrm{ml})$} \\
\cline { 2 - 5 } & \multicolumn{2}{|c|}{ Susceptible } & \multicolumn{2}{c|}{ Resistant } \\
\cline { 2 - 5 } & Opaque C1 & White C2 & Opaque C3 & White C4 \\
\hline \multirow{2}{*}{ FLU } & $6.5 \pm 1.1^{\mathrm{a}}$ & $15 \pm 3.0^{\mathrm{a}}$ & $76 \pm 14.0^{\mathrm{b}}$ & $200 \pm 34.0^{\mathrm{c}}$ \\
\hline
\end{tabular}

Mean \pm SD, $n=3$. Across the same row, means with the same letter superscript are homogenous (not significantly different at $P>0.05$ ), whereas those with different letters are significantly different at $P<0.05$.

Similar trend of result in case of TRB was observed when compared with FLU (Table 4) where the opaque $C$. albicans isolates C5 and C7 were more susceptible than the white ones (C6 and C7) and recorded lower $\mathrm{MIC}_{90}$ against TRB. The highly susceptible opaque isolate C5 to TRB was collected from the blood of a twelve days old female suffering from ectopia vesicae and tetralogy of fallot (TOF), and treated with two types of antibiotics, while the highly resistant white isolate $\mathrm{C} 8$ was isolated from blood of a two days old male suffering from skin cancer.

TABLE 4. MIC $_{90}$ values for TRB against $C$. albicans isolates .

\begin{tabular}{|c|c|c|c|c|}
\hline \multirow{2}{*}{ Treatment } & \multicolumn{4}{|c|}{ MIC $_{90}(\mu \mathrm{g} / \mathrm{ml})$} \\
\cline { 2 - 5 } & \multicolumn{2}{|c|}{ Susceptible } & \multicolumn{2}{c|}{ Resistant } \\
\cline { 2 - 5 } & Opaque C5 & White C6 & Opaque C7 & White C8 \\
\hline \multirow{2}{*}{ TRB } & $0.6 \pm 0.2^{\mathrm{a}}$ & $5 \pm 1.0^{\mathrm{a}}$ & $56 \pm 7.0^{\mathrm{b}}$ & $450 \pm 38.0^{\mathrm{c}}$ \\
\hline
\end{tabular}

Mean $\pm S D, n=3$. Across the same row, means with the same letter superscript are homogenous (not significantly different at $P>0.05$ ), whereas those with different letters are significantly different at $P<0.05$. 
Gene expression in C. albicans treated with antifungals

Expression of gene transcripts encoding both fluconazole and terbinafine resistance proteins was analyzed by semi-quantitative RT-PCR (Semi Q RT-PCR) for isolation of total RNA from different $C$. albicans isolates (Fig. 1). The PCR product of the $C$. albicans isolates resulted in a clear band on ethidium bromide stained, UVtransilluminated agarose gel. A single band of PCR product with the expected length on agarose gel electrophoresis also confirmed the specificity of the PCR reactions.

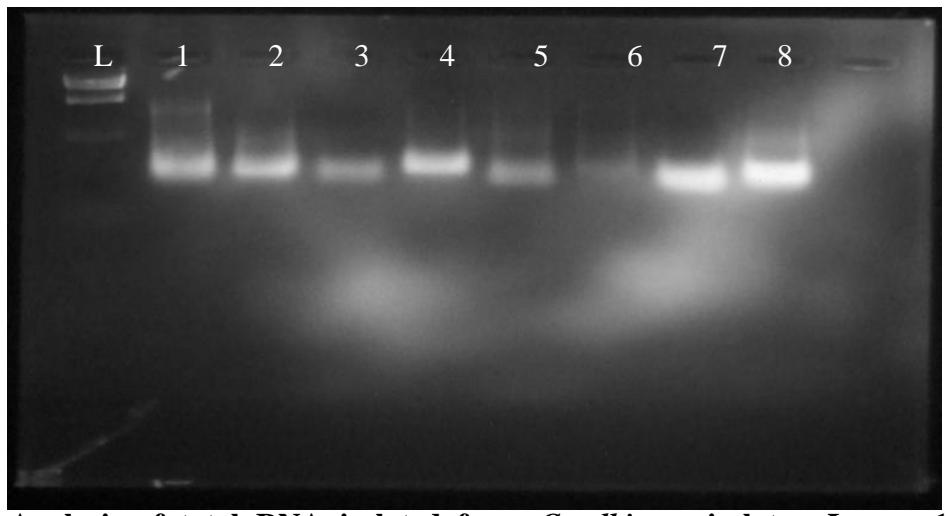

Fig. 1. Analysis of total RNA isolated from $C$. albicans isolates. Lanes: 1, FLUsusceptible opaque isolate C1; 2, FLU-susceptible white isolate C2; 3, FLUresistant opaque isolate $\mathrm{C3}$; 4 , FLU-resistant white isolate $\mathrm{C} 4$; 5 , TRBsusceptible opaque isolate C5; 6, TRB-susceptible white isolate C6; 7, TRBresistant opaque isolate $\mathrm{C7} ; 8$, TRB-resistant white isolate C8. Total RNA was resolved by denaturing agarose gel electrophoresis in 1X TAE buffer. RNA was dissolved in water $(2.5 \mu \mathrm{g} / \mu \mathrm{l})$ and mixed with deionized formamide to achieve a final concentration (v/v) of $50 \%$ formamide. L, RNA ladder (RiboRuler ${ }^{\mathrm{TM}}$ RNA ladder high range: 100-6000 bases) (Fermentas).

The expression levels of genes encoding lanosterol 14 $\alpha$-demethylase (ERG11); efflux transporters Candida multidrug resistance protein1 (CaMDRI) ; Candida drugresistance $C D R 1$ and $C D R 2$ and the major facilitator fluconazole-resistance gene (FLU1) implicated in fluconazole- resistance in C. albicans were monitored semiquantitatively by RT-PCR in matched sets of susceptible- and resistant isolates (Fig. 2 a-f). Upregulation folds were calculated based on relative comparison of the resistant with the susceptible strains according to $\mathrm{MIC}_{90}$ of the tested FLU and TRB.

\section{Resistance to FLU}

The results showed that ERG11 transcription level was seen only in the FLU resistant opaque C. albicans isolate C3 (Fig. 2-d and Table 5). The CDR1 efflux gene was up regulated (1.04 and 1.02 fold) in the FLU resistant opaque isolates $\mathrm{C} 3$ and FLU resistant white isolate $\mathrm{C} 4$, respectively, compared with the susceptible opaque isolates $\mathrm{C} 1$ and white isolate $\mathrm{C} 2$, respectively. FLU resistant opaque isolate $\mathrm{C} 3$ had the highest $C D R 1$ transcript level (a 1.02 fold increase than CDRI in FLU resistant white isolate C4; oppositely, no transcripts were detected for CaMDR1, CDR2, ERG11 and FLU1, genes in the FLU-susceptible C. albicans isolates (C1 \& C2) (Fig.2 b \& Table 5).

Egypt. J. Bot., 54, No. 1 (2014) 

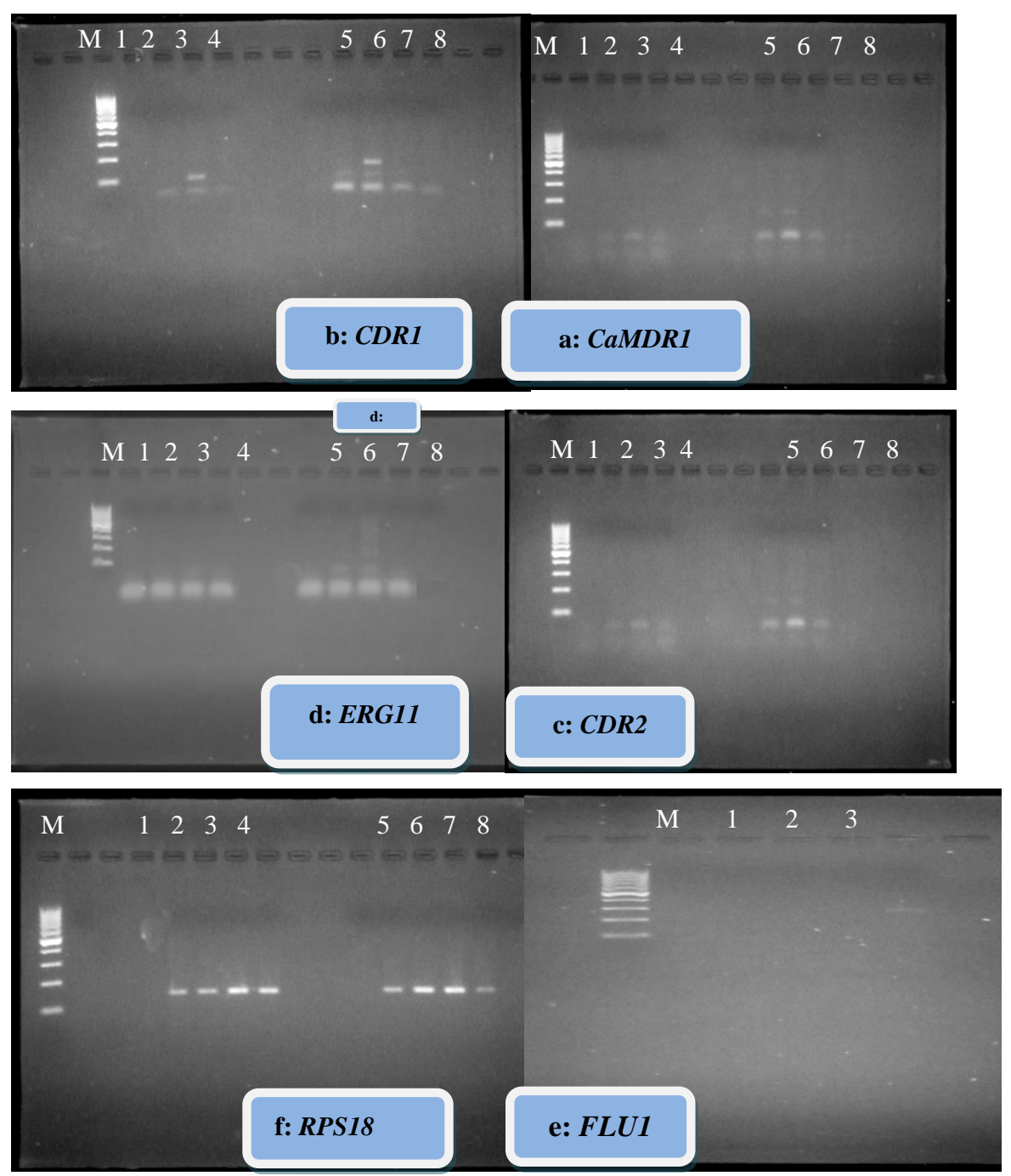

Fig. 2. Semi Q RT-PCR of resistant genes of $C$. albicans of both susceptible and resistant isolates for FLU and TRB. a-e, represented agarose gel electrophoresis of PCR product of different resistant genes, $C a$ MDR (148 bp), CDR1 (93 bp), CDR2 (125bp) and ERG11 (134 bp), FLU, (92 bp), and the reference housekeeping gene ribosomal protein S18 (RPS18). $5 \mu$ l of PCR products of the represented genes were analyzed on $1.5 \%$ agarose gel in $0.5 \mathrm{X}$ TBE and stained with ethidium bromide. Lane M: 100bp DNA ladder. Lanes: 1, C1; 2, C2; 3, C3; 4, C4 (fluconazole susceptible- and resistant-isolates) 5, C5; 6,C6; 7, C7; 8, C8 (T\terbinafine susceptible-and resistant-isolates). 


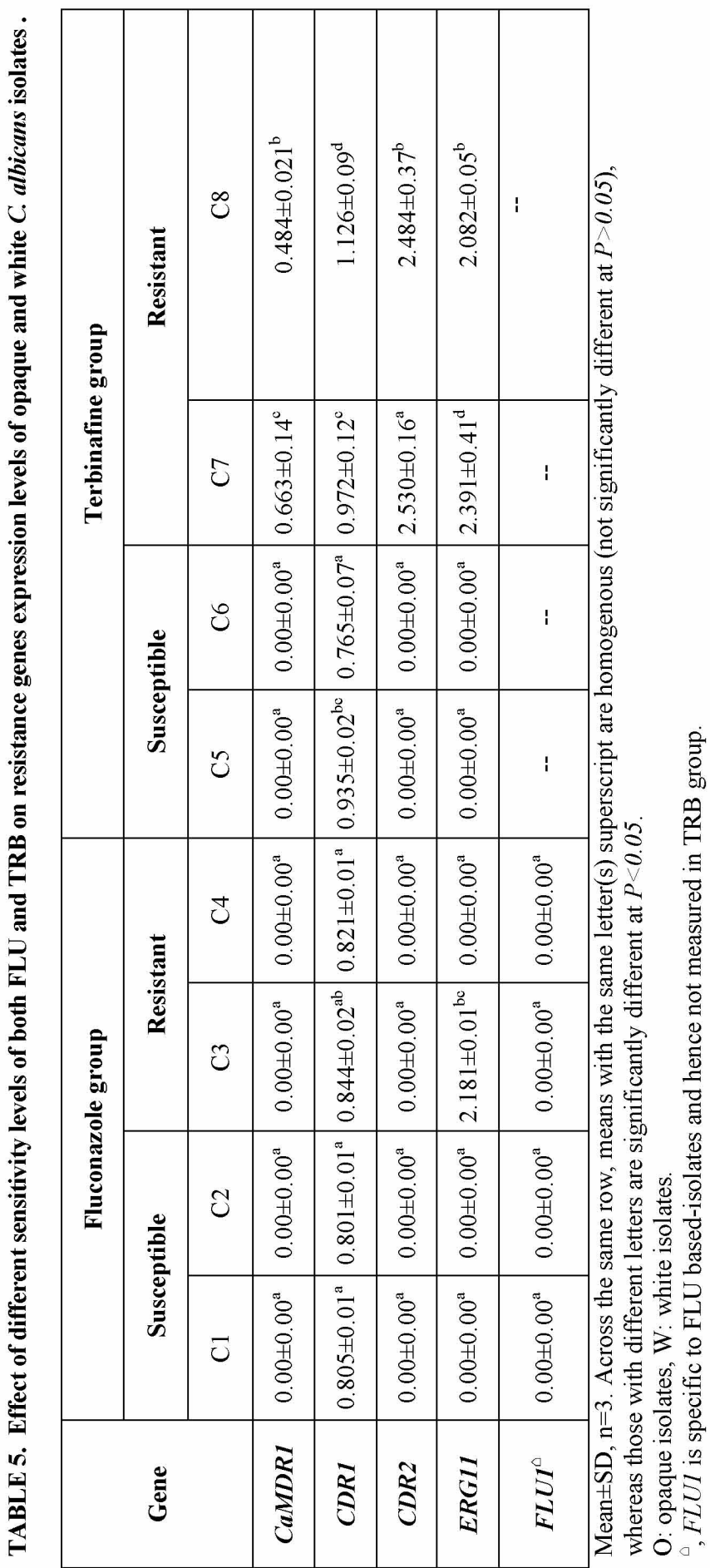

Egypt. J. Bot., 54, No. 1 (2014) 
The analysis confirmed that mechanisms of fluconazole-resistance in the four tested isolates of $C$. albicans exhibiting a predominance of over expression of CDR1 encoding efflux pumps, detected in all tested isolates, while, over

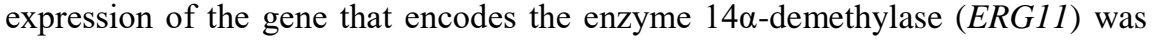
detected in $25 \%$ of the isolates specifically resistant opaque isolate C 3 only.

\section{Resistance to TRB}

The CDR1 efflux gene in the terbinafine-resistant white isolate $\mathrm{C} 8$ was up regulated 1.4 fold relative to susceptible white isolate C6. Similarly, 1.04 fold increased in CDR1 transcript level was observed in resistant opaque isolate C7 relative to the susceptible opaque isolate C5, (Fig.2 b \& Table 5). Resistant white isolate $\mathrm{C} 8 \mathrm{had}$ the highest $C D R 1$ expression level. The resistant opaque isolate $\mathrm{C} 7$ had higher up regulation in the $C D R 2$ transcript level (Fig.2 c) compared with the resistant white isolate C8. The expression of CaMDR1 (Fig. 2 a) and ERG11 had maximum expression in resistant opaque isolate $\mathrm{C} 7$ followed by white resistant isolate C8. It is worth mentioning that the susceptible white isolate $\mathrm{C} 6$ and resistant opaque isolate C5 did not transcript levels for CaMDR1, CDR2 or ERG11. However FLU1 gene not measured in all isolates (Table 5).

The expression of CDRI resistance gene by susceptible and resistant C. albicans isolates indicated the non selectivity in expressing this gene by Candida isolates. The environmental conditions, Candida spp. and patient conditions determined whether these genes are functioning or not. Furthermore, the expression of resistant gene $C D R I$ by susceptible isolates indicates that it may be expressed but not functioning. CaMDR1, CDR2, ERG11 genes were expressed in resistant white and opaque C. albicans isolates only (Table 5).

\section{Discussion}

Rapid and reliable antifungal susceptibility testing has become particularly important in recent years because of the emergency of antifungal - drug resistance (Asai et al., 1999). Opportunistic fungal infections have dramatically increased in recent years which prompted the pharmaceutical industry to respond with development of several new antifungal agents. Consequently, interest has increased in developing standardized tests to determine antifungal drug susceptibility and in optimizing those tests to accurately predict clinical outcome (Graybill et al., 1998).

In the current study, susceptibility tests and $\mathrm{MIC}_{90}$ determination were carried out on 49 Candida isolates (white and opaque forms) of C. albicans. Two antifungals with different groups and different mode of actions were tested: fluconazole (FLU) and terbinafine (TRB). Disk-diffusion test (NCCLS M44-A) was used. White-yeast form of $C$. albicans appeared highly susceptible to FLU and TRB. Among the 4 tested isolates of white $C$. albicans, isolates number $\mathrm{C} 2$ 
and C6 were highly susceptible, whereas, isolates number $\mathrm{C} 4$ and $\mathrm{C} 8$ were the most resistant to FLU and TRB, respectively. Among 4 assayed opaque $C$. albicans, isolate number $\mathrm{C} 1$ and $\mathrm{C} 5$ were highly susceptible to both FLU and TRB, while isolates number C3 and C7 were highly resistant to FLU and TRB, respectively. In general, the susceptibility tests indicated that opaque-form of $C$. albicans was more susceptible to the tested antifungals than white form.

In spite of FLU widespread use in medical community, many reports observed clinical failure in individuals with candidiasis due to FLU-resistant $C$. albicans strains especially in immunocompromised patients treated for chemotherapy or prophylaxis (Case et al., 1991; Martins et al., 1997; Rangel-Frausto et al., 1999; Krcmery and Barnes, 2002). Pelletier et al. (2002) applied NCCLS M27-A method to evaluate the antifungal activity of voriconazole (VRC) and fluconazole (FLU) against 295 Candida isolates collected from 189 patients. Forty two isolates had reduced susceptibility to FLU (MIC $>8 \mathrm{mg} / \mathrm{l}$ ); $83.3 \%$ of those had VRC MIC $\leq 2 \mathrm{mg} / 1$ (9 of 11 C. albicans, 18 of 19 C. glabrata, 6 of 6 C. krusei, 2 of 2 C. Lusitania and 0.0 of 4 C. tropicalis). This suggested that VRC exhibited fungicidal activity against abroad range of commonly FLU-resistant species.

In the current study, an experiment was designed to investigate, in the molecular level, the resistance mechanisms of $C$. albicans to FLU and TRB by semi-quantiation of the expression of some resistance genes using RT-PCR. These genes include Candida drug-resistance genes (CDR1 and CDR2), the gene encoding lanosterol $14 \alpha$-demethylase (ERG11), Fluconazole-resistance 1 gene (FLU1), and Candida multidrug-resistance 1gene (CaMDRI).

It was found that $C D R 1$ was upregulated by all Candida isolates whether it is white or opaque resistant or susceptible to FLU and TRB. This indicated that this gene is over expressed with any antifungal treatment but is functioning in the resistant isolates only. The genes $C D R 2$ and CaMDR1 are not expressed in all FLU treatments, while they expressed by resistant isolates (white and opaque) to TRB. ERG11 was expressed in the two resistant isolates C7\& C8 to TRB and the opaque resistant isolate $\mathrm{C} 3$ to FLU. This means that CaMDR1, CDR2 and ERG11 genes are associated with resistance of $C$. albicans to antifungals. FLU1 gene was not expressed by $C$. albicans in all cases. It is worth noting that in all susceptible isolates $C D R 1$ was the only expressed gene.

The most common azole resistance mechanism in C. albicans has been reported to be a reduced intracellular accumulation of the drug as a result of reduced influx and / or increased efflux (Ryley et al., 1984; Venkateswarlu et al., 1997). Evidence has been presented that efflux of azole drugs from fungal cells is due to energy-dependent pumps (Vanden Bossche et al., 1992). Correlation between over expression of $C D R 1$ and $C D R 2$ genes, which are members of ATPbinding cassette $(\mathrm{ABC})$ super family, and CaMDRI gene of Major Facilitator Super family (MSF) and azole resistance by $C$. albicans were detected by several investigators (Sanglard et al., 1995; 1997; White, 1997; Franz et al., 1998). Over

Egypt. J. Bot., 54, No. 1 (2014) 
expression of $C D R 1$ and $C D R 2$ without any energy dependent efflux was demonstrated by Sanglard et al. (1995). This suggests that although these genes expressed but they are not functioning. High expression of MDRI1 in some FLUsusceptible isolates has been seen by (White et al., 2002; Goldman et al., 2004).

$C D R 1, C D R 2$ and CaMDR1 are genes proposed to encode cell memberaneassociated transporters which act as possible mediator to enhance FLU efflux and they are responsible for the export of several azole drugs (Fling et al., 1991; Sanglard et al., 1995; 1997; White, 1997; Franz et al., 1998). CDR2 conferred hyper resistance to the antifungal capsfungin, while it enhanced susceptibility to the antifungal micofungin. This indicated that the increased functional expression of $c d r l p$ and $c d r 2 p$ didn't give significant candin resistance in C. albicans strains. Chen et al. (2010) reported that $C D R 1$ and $C D R 2$ were upregulated in all FLUresistant $C$. albicans isolates whereas only a few isolates showed high expression of CaMDRI, FLU1 and ERG11 genes compared with control strain. They concluded that over expression of $C D R 1$ and $C D R 2$ genes may play role in FLUresistant $C$. albicans.

In all fungal species, ERG11 (gene encoding Erg11-p or lanosterol $14 \alpha-$ demethylase) is an essential gene for ergosterol synthesis. Over expression of ERG11 causes an increased copy number of the enzyme lanosterol $14 \alpha-$ demethylase and results in increased ergosterol biosynthesis which reduced the efficiency of the antifungal drugs against $C$. albicans (Holmberg and Stevens, 1999; Perea et al., 2002). The alternation in pathway of ergosterol synthesis in amphotericin B-resistant C. albicans involve ERG11 gene (Liu et al., 1996). Mutation in ergosterol synthesis pathway genes including ERG11 modifies the site of amphoteicin B activity (Kumar and Shakla, 2010), ERG11 gene over expression result in conformational changes that reduce the effective binding between azoles and their target (Rodriguez-Tudela et al., 1996). Despite this, an investigator has concluded that there is no obvious link between the expression levels of ERG11 and increased azole resistance (White et al., 2002). Chen et al., (2010) indicated poor correlation between ERGII over expression with FLU resistance. Thus, at least four common explanations of the mechanisms of azole resistance in C. albicans:

1- Alternation of drug target enzymes such as a point mutation in ERG11 that can affect the affinity between drugs and the target enzyme.

2- Overexpression of drug resistance genes in C. albicans (CDR1\& CDR2) and the multidrug resistance 1 gene (CaMDR1).

3- Overexpression of the major facilitator resistance gene FLU1 which found to increase FLU-resistance by $C$. albicans. 


\section{References}

Asai, K., Tsuchimori, N., Okonogi, K., Perfect, J.R., Gotoh, O. and Yoshida, Y. (1999) Formation of azole-resistant Candida albicans by mutation of sterol 14-demethylase P450. Antimicrob. Agents Chemother., 43, 1163-1169.

Casalinuovo, I.A., Di Francesco, P. and Garaci, E. (2004) Fluconazole resistance in Candida albicans: a review of mechanisms. Eur. Rev. Med. Pharmacol. Sci., 8, 69-77.

Case, C.P., Macgowan, A.P., Brown, N.M., Reeves, D.S., Whitehead, P. and Felmingham, D. (1991) Prophylactic oral fluconazole and candida fungaemia. Lancet, 337, 790 .

Chen, L.M., Xu, Y.H., Zhou, C.L., Zhao, J., Li, C.Y. and Wang, R. (2010) Overexpression of CDR1 and CDR2 genes plays an important role in fluconazole resistance in Candida albicans with G487T and T916C mutations. J. Int. Med. Res., 38, 536-545.

Clinical and Laboratory Standards Institute (CLSI). (2009) "Method for Antifungal Disk Diffusion Susceptibility Testing of Yeasts"; approved guideline, $2^{\text {nd }}$ ed., M44-A2 Clinical and Laboratory Standards Institute, Wayne, PA.

Fling, M.E., Kopf, J., Tamarkin, A., Gorman, J.A., Smith, H.A. and Koltin, Y. (1991) Analysis of a Candida albicans gene that encodes a novel mechanism for resistance to benomyl and methotrexate. Mol. Gen. Genet., 227, 318-329.

Franz, R., Kelly, S.L., Lamb, D.C., Kelly, D.E., Ruhnke, M. and Morschhauser, J. (1998) Multiple molecular mechanisms contribute to a stepwise development of fluconazole resistance in clinical Candida albicans strains. Antimicrob. Agents Chemother., 42, 3065-3072.

Goldman, G.H., da Silva Ferreira, M.E., dos Reis Marques, E., Savoldi, M., Perlin, D., Park, S., Godoy Martinez P.C., Goldman, M.H. and Colombo, A.L. (2004) Evaluation of fluconazole resistance mechanisms in Candida albicans clinical isolates from HIV-infected patients in Brazil. Diagn. Microbiol. Infect Dis., 50, 25-32

Graminha, M.A., Rocha, E.M., Prade, R.A. and Martinez-Rossi, N.M. (2004) Terbinafine resistance mediated by salicylate 1-monooxygenase in Aspergillus nidulans. Antimicrob. Agents Chemother., 48, 3530-3535.

Graybill, J.R., Montalbo, E., Kirkpatrick, W.R., Luther, M.F., Revankar, S.G. and Patterson, T.F. (1998) Fluconazole versus Candida albicans: a complex relationship. Antimicrob. Agents Chemother., 42, 2938-2942.

Holmberg, K. and Stevens, D.A. (1999) Resistance to antifungal drugs: current status and clinical implications. Curr. Opin. Anti-Infective Invest. Drugs, 1, 306-317.

Krcmery, V. and Barnes, A.J. (2002) Non-albicans Candida spp. causing fungaemia: pathogenicity and antifungal resistance. J. Hosp. Infect., 50, 243-260.

Kucers, A., Crowe, S.M., Grayson, M.L. and Hoy, J. (1997) "The Use of Antibiotics: A Clinical Review of Antibacterial, Antifungal and Antiviral Drugs", $5^{\text {th }}$ ed. Oxford, England, Butterworth- Heinemann.

Egypt. J. Bot., 54, No. 1 (2014) 
Kumar, R. and Shukla, P.K. (2010) Amphotericin B resistance leads to enhanced proteinase and phospholipase activity and reduced germ tube formation in Candida albicans. Fungal Biol., 114, 189-197.

Liu, L.T., Lin, Y.C., Wang, C.J., Lin, M.S., Yen, S. and Chen, H. (1996) Synthesis and Biological-activities of a novel class of azole-containing antifungal agents. Bioorg. Med. Chem. Lett., 6, 1335-1338.

Martins, M.D., Loza No-Chiu, M. and Rex, J.H. (1997) Point prevalence of oropharyngeal carriage of fluconazoleresistant Candida in human immunodeficiency virus-infected patients. Clin. Infect. Dis., 25, 843-846.

Masek, T., Vopalensky, V., Suchomelova, P. and Pospisek, M. (2005) Denaturing RNA electrophoresis in TAE agarose gels. Anal. Biochem., 336, 46-50.

Pelletier, R., Loranger, L., Marcotte, H.L.N. and De Carolis, E. (2002) Voriconazole and fluconazole susceptibility of Candida isolates. J. Med. Microbiol., 51, 479-483.

Perea, S., Lòpez-Ribot, J.L., Wickes, B.L., Kirkpatrick, W.R., Dib, O.P., Bachmann, S.P., Keller, S.M., Martinez, M. and Patterson, T.F. (2002) Molecular mechanisms of fluconazole resistance in Candida dubliniensis isolates from human immunodeficiency virus-infected patients with oropharyngeal candidiasis. Antimicrob. Agents Chemother., 46, 1695-1703.

Rangel-Frausto, M.S, Wiblin, T., Blumberg, H.M., Saiman, L., Patterson, J., Rinaldi, M., Pfaller, M., Edwards, J.E. Jr, Jarvis, W., Dawson, J. and Wenzel, R.P. (1999) National epidemiology of mycoses survey (NEMIS): variations in rates of bloodstream infections due to Candida species in seven surgical intensive care units and six neonatal intensive care units. Clin. Infect. Dis., 29, 253-258.

Rodriguez-Tudela, J.L., Berenguer, J., Martinez-Suarez, J.V. and Sanchez, R. (1996) Comparison of a spectrophotometric microdilution method with RPMI $\pm 2 \%$ glucose with the National Committee for Clinical Laboratory Standards reference macrodilution method M27-P for in vitro susceptibility testing of amphotericin B, flucytosine, and fluconazole against Candida albicans. Antimicrob. Agents Chemother., 40, 1998-2003.

Ryder, N.S. (1992) Terbinafine: Mode of action and properties of the squalene epoxidase inhibition. Br. J. Dermatol., 126 (Suppl. 39), 2-7.

Ryder, N.S. and Favre, B. (1997) Antifungal activity and mechanism of action of terbinafine. Rev. Contemp. Pharmacother., 8, 275-287.

Ryder, N.S., Seidl, G. and Troke, P. (1984) Effect of the antimycotic drug naftifine on growth of and sterol biosynthesis in Candida albicans. Antimicrob. Agents Chemother., 25, 483-487.

Ryley, J.F., Wilson, R.G., and Barrett-Bee, K.J. (1984) Azole resistance in Candida albicans. Sabouraudia, 22, 53-63. 
Sanglard, D., Ischer, F., Monod, M. and Bille, J. (1997) Cloning of Candida albicans genes conferring resistance of azole antifungal agents: characterization of CDR2, a new multidrug ABC transporter gene. Microbiology, 143, 405-416.

Sanglard, D., Kuchler, K., Ischer, F., Pagani, J.L., Monod, M. and Bille, J. (1995) Mechanisms of resistance to azole antifungal agents in Candida albicans isolates from AIDS patients involve specific multidrug transporters. Antimicrob. Agents Chemother. 39, 2378-2386.

Saxen, H., Hoppu, K. and Pohjavuori, M. (1993) Pharmacokinetics of fluconazole in very low birth weight infants during the first two weeks of life. Clin. Pharmacol. Ther., 54, 269-277.

Vanden Bossche, H., Marichal, H.P., Odds, F., Le Jeune, L. and Coene, M.C. (1992) Characterization of an azole-resistant Candida glabrata isolate. Antimicrob. Agents Chemother., 36, 2602-2610.

Venkateswarlu, K., Denning, D.W., and Kelly, S.L. (1997) Inhibition and interaction of cytochrome P450 of Candida krusei with azole antifungal drugs. J. Med. Vet. Mycol., 35, 19-25.

White, T.C. (1997) Increased mRNA levels of ERG16, CDR, and MDR1 correlate with increases in azole resistance Candida albicans isolates from a patient infected with human immuno-deficiency virus. Antimicrob. Agents Chemother., 41, 1482-1487.

White, T.C, Holleman, S., Dy, F., Mirels, L.F., and Stevens, D.A. (2002) Resistance mechanisms in clinical isolates of Candida albicans. Antimicrob. Agents Chemother. 46, 1704-1713.

(Received 26/9/2013;

accepted $1 / 10 / 2013$ 
في الكبانديدا البيكانز العزلات الحساسة و المقاومة لمضدات الفطريات

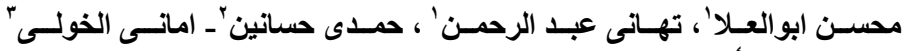

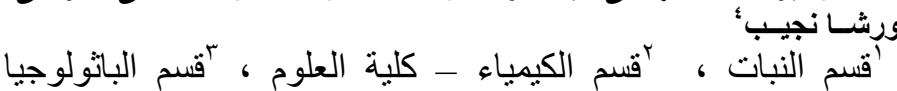

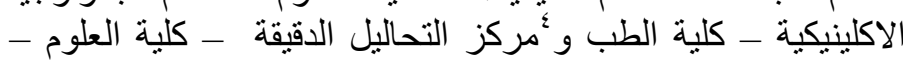

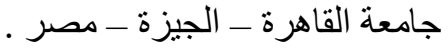

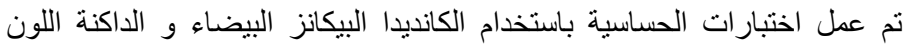

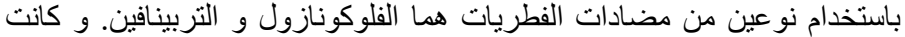

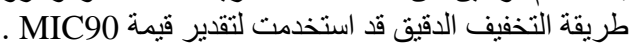

و قد وجد ان كلا المضادين الفطريين المسخدمين كانا نشطين ضد الكاءناندانديدا البيكانز البيضاء و الداكنة اللون، و قد كان الفلوكونازول اكثر كفاءة من التربينافين.

لقد تم تقديرة التعبير عن خمسة جينات مقاومة باستخدام RT-PCR بعد الندام

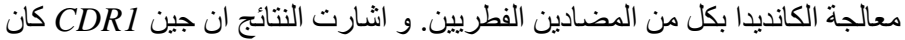
الاكثر تعبيرا فى العزلات الحساسة و المقاومة كما كان جين النين CaMDRl

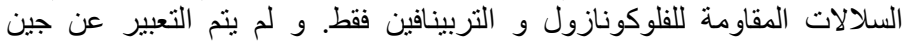

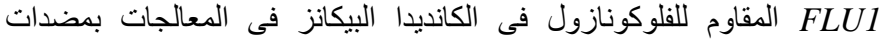

